This item was submitted to Loughborough's Research Repository by the author.

Items in Figshare are protected by copyright, with all rights reserved, unless otherwise indicated.

\title{
Briefing: challenging lock-in through urban energy systems
}

PLEASE CITE THE PUBLISHED VERSION

http://dx.doi.org/10.1680/udap.2010.163.4.149

PUBLISHER

(C) ICE Publishing / The authors

VERSION

VoR (Version of Record)

LICENCE

CC BY-NC-ND 4.0

REPOSITORY RECORD

Rydin, Yvonne, Patrick Devine-Wright, Chris I. Goodier, Simon Guy, Lester Hunt, and Jim Watson. 2019. "Briefing: Challenging Lock-in Through Urban Energy Systems". figshare. https://hdl.handle.net/2134/7806. 
This item was submitted to Loughborough's Institutional Repository (https://dspace.lboro.ac.uk/) by the author and is made available under the following Creative Commons Licence conditions.

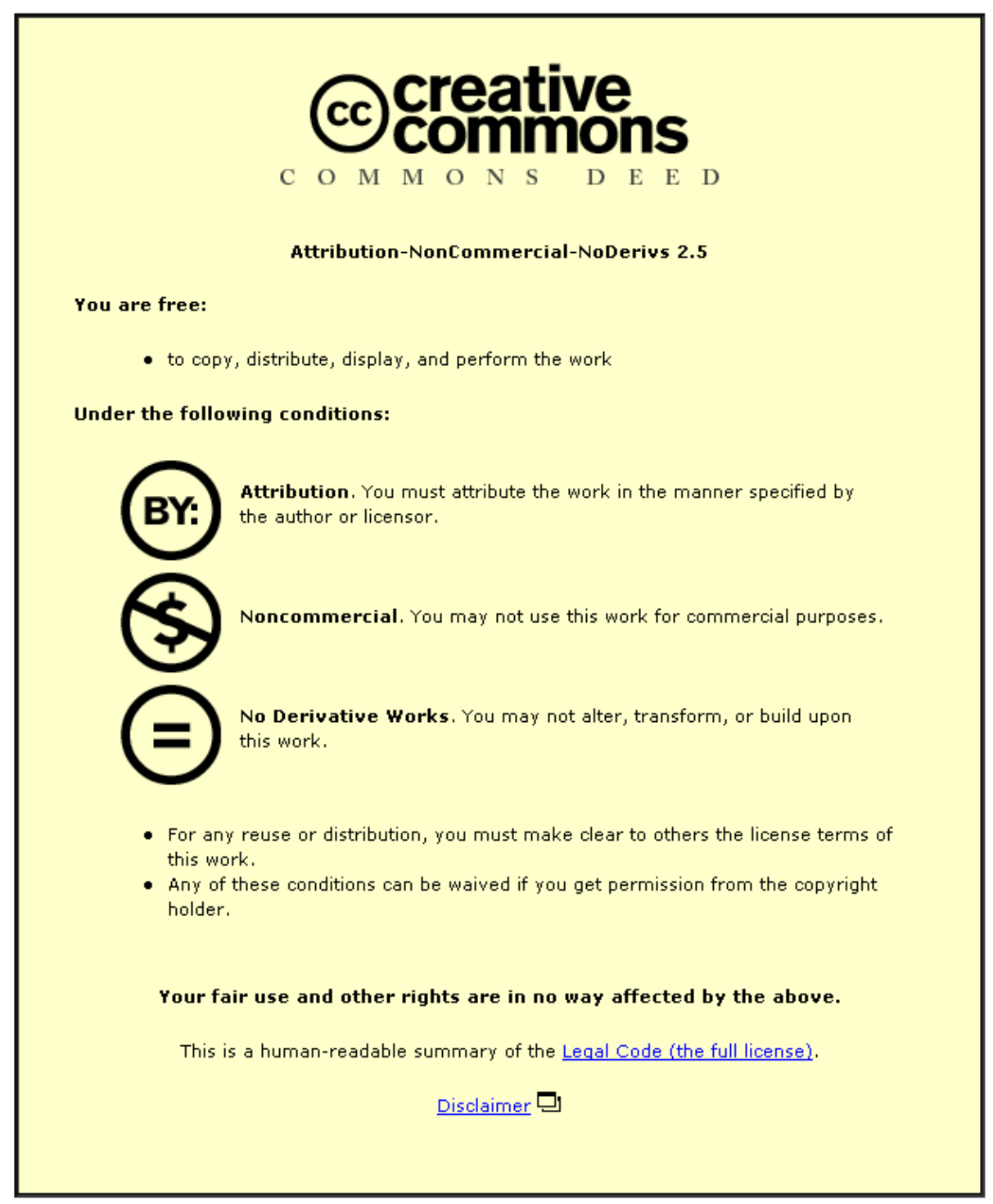

For the full text of this licence, please go to: http://creativecommons.org/licenses/by-nc-nd/2.5/ 
Yvonne Rydin Professor of Planning, Environment and Public Policy \& Director of the UCL Environment Institute, University College London, UK
Patrick Devine-Wright Professor of Human Geography, University of Exeter, UK

Jim Watson

Director, Sussex Energy

Group, University of Sussex, UK
Chris Goodier

Lecturer in Civi

Engineering,

Loughborough

University, UK
Simon Guy

Professor of

Architecture and

Director of the

Manchester

Architecture Research

Centre University of

Manchester, UK

\section{Briefing: Challenging lock-in through urban energy systems}

\section{Y. Rydin PhD, MRICS, P. Devine-Wright PhD, MPS, C. Goodier PhD, Pg Cert, MCIOB, MICT, FHEA, S. Guy PhD,} L. Hunt MA, PhD and J. Watson PhD

\section{Challenging lock-in through urban energy systems (Clues) is a major new research project funded by the Engineering and Physical Sciences Research Council. This briefing sets out the focus and approach of the project and the key research questions that it will address.}

\section{BACKGROUND}

As set out in the UK government's low-carbon transition plan, achieving substantial cuts in carbon dioxide emissions is the most pressing challenge facing the UK in the period to 2050 (HMG, 2009). The depth of this challenge has been emphasised by the Committee on Climate Change (CCC) in its call for a further 'step change' in emissions reductions (CCC, 2009). Restructuring the UK's energy system will be central to fulfilling the government's goal of $80 \%$ cuts, but the current system is characterised by lock-in into centralisation (GOS, 2008). This lock-in is, however, not only a technological phenomenon. Centralised energy technologies such as large power stations and national grids are reinforced by market rules, institutional arrangements, business models and social norms that make the energy system difficult to change.

There is, though, potential for challenging this lock-in through action at the urban scale. More decentralised systems are increasingly being promoted at the urban scale through innovative urban development, the role of local planning systems, targeted subsidies for the installation of new technologies, the introduction of the clean energy cashback (a feed-in tariff) and initiatives such as the Department of Energy and Climate Change low-carbon communities challenge (DECC, 2010) and local government responses arising from the Sustainable Communities Act 2007 (DCLG, 2010). Such decentralised urban energy systems can cover a range of scales and encompass a variety of ways of achieving carbon reductions, including the deployment of low-carbon technologies, new institutional arrangements, social innovation and revised policy frameworks. And such systems are changing the face of the UK's urban areas. However, this raises urgent questions.

(a) What barriers will such urban energy systems face if pursued on a substantial scale?

(b) What are the implications for the integration of decentralised systems into the UK energy system at urban, regional and national levels? (c) What contribution could such urban energy systems make to aggregate decarbonisation targets over the period to 2050?

(d) What role do urban energy systems play in the making of sustainable places and communities in urban areas?

\section{PROJECT FOCUS}

Challenging lock-in through urban energy systems (Clues), a project funded by the Engineering and Physical Sciences Research Council (EPSRC) and due to run for 2 years from October 2010, will critically assess the pursuit of decentralised energy systems in urban areas in the light of the need to achieve national decarbonisation goals to 2050 and broader urban sustainability goals. As such, the project is distinguished from previous research on energy decentralisation that has tended to examine individual cases of best practice primarily for their performance and transferability and tended to ignore how they are embedded in specific urban design, development and governance processes (Energy Policy, 2008: section 6). Instead, the Clues project will focus on:

(a) the scope for and the implications of scaling up the many individual instances of decentralised urban energy projects to challenge lock-in to a centralised energy system

(b) understanding how the greater emphasis on such decentralisation will reshape the urban environment.

The project will deliver an assessment of the contribution of decentralised urban energy systems to national decarbonisation goals. It will provide an understanding of how the barriers and drivers of urban energy initiatives have implications for energy systems at different scales, rather than just for the success of individual projects (e.g. Fisk, 2008). It will develop a methodology for scaling up from individual initiatives that will be internationally significant and will drive research agendas. More generally, the project will contribute to policy and practice by reframing the contribution of urban energy systems and ensuring that their promotion will both underpin integration of energy systems and maximise carbon efficiencies. This will reframe the current policy approach to pursuing urban energy initiatives which, to date, has focused on encouraging such initiatives in all new developments and through established community structures. The result could be a very different pattern of energy systems, combining different scales on the basis of informed analysis rather than leaving the evolution of the energy system to arise from the ad hoc proliferation of bottom-up initiatives in an otherwise centralised context. 
The project will also set this work on energy systems within the context of scenarios envisaging the urban environment in 2050 in both quantitative and qualitative terms. To understand the implications for urban areas of unlocking the energy system to a greater variety of scales (Keirstead, 2008), the project will make use of the 2050 scenarios developed with the involvement of the project team as part of the Foresight report on sustainable energy management and the built environment (GOS, 2008).

These scenarios were built to understand the potential variety in future pathways to sustainability over the period to 2050 in the face of key uncertainties. Four scenarios were derived, comprising a detailed qualitative narrative of how urban environments may change by 2050 and setting this in a broad understanding of urban sustainability, not limited to carbon reductions. Rather than assuming that there is a single optimal vision for sustainable urban environments and their associated energy systems in 2050, the project will work with these uncertainties and multiple pathways towards 2050 and use these to understand how challenging lock-in may generate different forms of sustainable urban environment within this timescale.

\section{PROJECT FRAMEWORK}

The project framework starts from the premise that the widespread diffusion of urban energy initiatives to help meet the UK's low-carbon goals will imply a significant socio-technical transition for the energy system (Marcotullio and Schulz, 2007). Recent studies of such socio-technical transitions have argued that lock-in is multi-faceted (Unruh, 2000) and that future transitions can only be analysed and understood from a multifaceted perspective. According to Geels et al. (2008) 'such transitions not only entail new technologies, but also changes in markets, user practices, policy and cultural discourses, and governing institutions'. The project therefore uses a coevolutionary framework $(\mathrm{CoF})$ in order to tackle the combination of technological, governance, economic and cultural factors that characterise lock-in. This approach (Brand, 2005; Guy, 2006; Kemp and Rotmans, 2005) sees behaviours (not only driving energy consumption and associated carbon emissions but also urban transformation) as multiply determined by a mix of factors, across scales from the household through local communities to regions and national levels. It brings into dialogue technical and institutional processes, infrastructural and place-based perspectives, and the economic and sociopsychological dimensions of urban energy systems.

\section{RESEARCH QUESTIONS AND OBJECTIVES}

The overarching research questions the project will answer are as follows.

(a) What is the contribution to carbon reductions at a national scale that can be achieved by the greater deployment of urban energy initiatives having regard to the need to integrate energy systems across scales?

(b) What are the implications of this promotion of urban energy systems for change in urban environments to 2050 and for the sustainability of urban areas?

The project has the following specific objectives.

(a) To develop an interdisciplinary approach to understanding related change in energy systems and urban environments through a focus on the deployment of urban energy initiatives.

(b) To explore and understand the drivers and barriers influencing the success and failure of urban energy initiatives and relate these to the urban, regional and national context.

(c) To undertake a comparative analysis of urban energy initiatives in the UK and internationally to understand the processes involved in moving from the local exemplar to practices that are replicable at different scales and in different local contexts.

(d) To assess the role that such local urban energy initiatives could play in decarbonising UK society by scaling up the contribution of urban energy initiatives.

(e) To consider the implications of greater deployment of urban energy initiatives for transforming urban environments along sustainable paths to 2050 .

(f) To disseminate the key lessons of the project regarding the transferability, viability and aggregate impact of best practice to relevant stakeholders, including industrial, community and policy decision-makers.

(g) To contribute to the academic literature on energy systems, urban planning and urban change from an interdisciplinary perspective.

To answer these questions and meet these objectives, the methodology mixes quantitative and qualitative techniques, with an emphasis on interdisciplinarity and building links between the different work packages tackling different dimensions of how to challenge lock-in and achieve the transformative potential of urban energy initiatives. The key elements of the projects are:

(a) auditing and analysing existing urban energy initiatives

(b) quantification and development of 2050 scenarios

(c) assessment of implementation case studies within the UK

(d) assessment of innovation case studies from outside the UK

(e) the scaling up exercise to 2050

(f) the final synthesis.

Further information about the project can be obtained from the principal investigator, Professor Yvonne Rydin (email: Y.Rydin@ucl.ac.uk).

\section{REFERENCES}

Brand R (2005) Synchronizing Science and Technology with Human Behaviour. Earthscan, London.

CCC (Committee on Climate Change) (2009) Meeting the Carbon Budgets: The Need for a Step Change. CCC, London.

DCLG (Department of Communities and Local Government) (2010) http://www.communities.gov.uk/publications/localgovernment/ sustainablecommunitiesact (accessed 15/09/2010).

DECC (Department of Energy and Climate Change) (2010) http:// www.decc.gov.uk/en/content/cms/what_we_do/consumers/ lc_communities/ (accessed 15/09/2010).

Energy Policy (2008) Special issue: foresight sustainable energy management and the built environment project. Energy Policy 36(12): 4299-4667.

Fisk D (2008) What are the risk-related barriers to, and opportunities for, innovation from a business perspective in the UK, in the context of energy management in the built environment? Energy Policy 36(12): 4615-4617. 
Geels FW, Hekkert MP and Jacobsson S (2008) The microdynamics of sustainable innovation journeys. Technology Analysis \& Strategic Management 20(5): 521-536.

GOS (Government Office for Science) (2008) Powering Our Lives: Sustainable Energy Management and the Built Environment. GOS, London.

Guy S (2006) Designing urban knowledge: competing perspectives on energy and buildings. Environment and Planning $C$ 24(5): 645-659.

HMG (Her Majesty's Government) (2009) The UK Low Carbon Transition Plan. The Stationery Office, London.

Kemp R and Rotmans J (2005) The management of the co-evolution of technical, environmental and social systems. In Towards Environmental Innovation Systems (Weber M and Hemmelskamp J (eds)). Springer, Heidelberg, pp. 33-55.

Keirstead J (2008) What changes, if any, would increased levels of low-carbon decentralised energy have on the built environment? Energy Policy 36(12): 4518-4521.

Marcotullio PJ and Schulz NB (2007) Comparison of energy transitions in the United States and developing and industrializing economies. World Development 35(10): 1650-1683.

Unruh GC (2000) Understanding carbon lock-in. Energy Policy 28(12): 817-830.

\section{What do you think?}

To discuss this briefing, please email up to 500 words to the editor at journals@ice.org.uk. Your contribution will be forwarded to the author(s) for a reply and, if considered appropriate by the editorial panel, will be published as discussion in a future issue of the journal.

Proceedings journals rely entirely on contributions sent in by civil engineering professionals, academics and students. Papers should be 2000-5000 words long (briefing papers should be 1000-2000 words long), with adequate illustrations and references. You can submit your paper online via www.icevirtuallibrary.com/content/journals, where you will also find detailed author guidelines. 